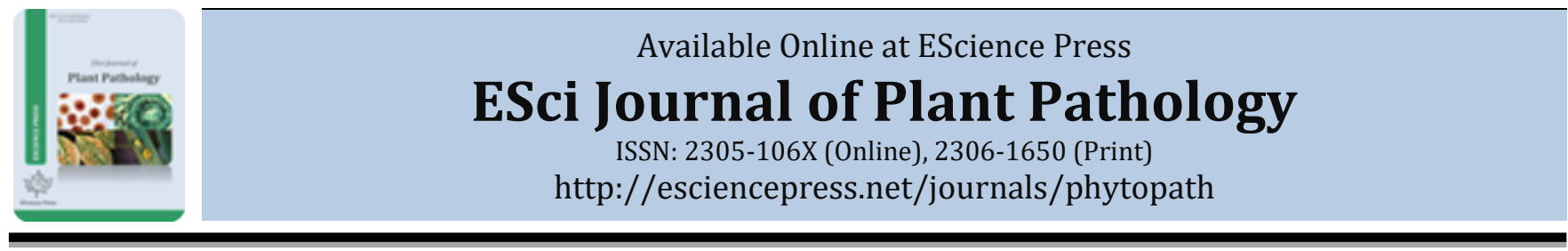

\title{
GENOTYPIC DIVERSITY OF POTATO GERMPLASM AGAINST ROOT KNOT NEMATODE (MELOIDOGYNE INCOGNITA) INFECTION IN PAKISTAN
}

\author{
Amjad S. Gondal*, Nazir Javed, Sajid A. Khan, Sajjad Hyder \\ Department of Plant Pathology, University of Agriculture Faisalabad, Pakistan.
}

*Corresponding Author Email: amjadshahzad@live.com

\section{A B S T R A C T}

Potato (Solanum tuberosum), an important vegetable crop of Pakistan endures significant yield losses due to root knot nematode (Meloidogyne incognita). Research wok was designed to identify resistant potato germplasm against RKN (Meloidogyne incognita) infection. A field trial was conducted in the research area of Department of Plant Pathology, University of Agriculture Faisalabad. Thirty six (36) potato verities/ cultivars relocated five times were sown in four years sick plot containing root knot nematode (Meloidogyne incognita) in RCBD layout. Root knot nematode reproduction and host damage was accessed by recording nematode root galls and egg mass indices, root weight, shoot weight, , number of leaves, fruit weight, rate of reproduction and final population of nematodes. Experiment revealed a considerable variation in response against Meloidogyne incognita infection among the genotype tested but none of the single cultivar was immune. FD-8-1 was used as negative control. The cultivar FD-19-2 was highly susceptible followed by SH-692 and SH-5. All other cultivars had less galling index with low fecundity rate indicating their ability to suppress the adult female reproduction. The cultivar FD-1-3 scored least number of galls and egg mass indices followed by FD-49-62, SH-339 and SH-332.

Keywords: Root knot nematode, Meloidogyne incognita, Genotypic response, Potato, Solanum tuberosum.

\section{INTRODUCTION}

Potato (Solanum tuberosum L.) is perennial solanaceous vegetable crop also known as nightshades. It is grown in 140 countries of the world (Haase, 2008). It endures significant yield losses due to biotic and abiotic stresses (Agrios, 2005). It is attacked by numerous fungal, bacterial, viral and nematode diseases that reduce both quality and quantity of the produce. Among biological agents, nematodes especially root knot nematodes (RKN) inflict heavy yield reduction (Anwar et al., 2009). Root knot nematodes are parasitic on a broad range of vegetable crops. They stand out as the major group of plant parasitic nematodes in almost all vegetable crops especially on potato and cause enormous yield losses (Mehrotra, 1983). Root knot nematodes (Meloidogyne incognita) are endoparasites that are distributed in tropical, subtropical and warmer regions of the world where the climate is suitable for their reproduction throughout the year. Meloidogyne spp. with an approximate distribution of $M$. incognita 58\%, M. javanica 31\%, M. aranaria 8\%, M. hapla $7 \%$ and other species are about $2 \%$ have been recorded in the agricultural soils of Pakistan (Maqbool, 1986). The presence of root knot nematodes with different vegetables, ornamental \& medicinal plants and fruit trees have been reported in Pakistan and other countries (Das and Das, 2000; Ravichandra and Krishnappa, 2004; Khan et al., 2006; Arooj, 2011). Two species of root knot nematodes; $M$. incognita and $M$. javanica have been reported to parasitize potato in almost all potato growing areas of Punjab (Anwar et al., 1991; Khan and Ahmad, 2000; Anwar et al., 2007).

$M$. incognita cause more losses to the vegetables especially to potato crops grown in the sandy loam soils of Punjab (Anwar and Mckenry, 2006). Root knot nematodes are amongst the damaging of plant parasitic nematodes. The genus Meloidogyne has more than 80 known species (Karseen, 2000). The most destructive species in the tropics and the subtropics include $M$. javanica, M. aranaria and M. incognita (Sikora and 
Fernandez, 2005). On account of great losses, they require immediate and due attention to control its predation (Rehman et al., 2006).

Root knots and gall formation of variable size is the characteristic symptoms of root knot nematode infection. Root galls cause disturbance in nutrient absorption, water essential elements uptake from the soil that leads to the poor plant growth ultimately severe yield losses (Hollis, 1963; Gowen et al., 2005). up to $95 \%$ annual yield losses were observed in vegetables due to high infestation of Meloidogyne incognita spp. (Bourne et al., 2004; Cetintas and Yarba, 2010).

Root knot nematodes are problematic to control because of their high population densities and reproductive potential (Sikora and Fernandez, 2005). RKN population was determined from different vegetable crops including tomato, potato, cucumber and squash (Karajeh et al., 2005; Kepenekci and Evlice, 2004).

An efficient and environment friendly way to prevent widespread destruction by nematode infections is to incorporate genotypic natural resistance in potato germplasm. The use of resistant genotypes is an attractive alternate for managing yield losses caused by plant parasitic nematodes which does not require major adaptations in the farming practices (Younis et al., 2009).

Resistant plant inhibits the reproduction of nematode species. Resistance of plant to nematode may be defined as plant ability to inhibit the attack of nematode. Resistance is widely and effectively used in vegetable and field crops (Anwar et al., 2007) such as tomato (Khan et al., 2000; Amin, 2003; Sajjad, 2004; Anwar et al., 2007; Abbas et al., 2008), Sugar beet (Zia et al., 2008), Chilli (Anwar et al., 2007) Cucumber (Anwar et al., 2007) and Soybean (Anwar, 1996; Ashiq et al., 2004). Different germplasm responds differently to diseases and pest attacks. The variation in response to nematode infection in different cultivars could be related to their genetic makeup and the level of resistance mechanism possessed by a particular cultivar (Abad et al., 2003; Barham and Winstead, 1957; Anwar and Mckenry, 2002). Varietal response against $M$. incognita infection of different vegetables is accessed on the basis of plant growth parameters including root weight, shoot weight, shoot height, number of leaves per plant and nematode reproduction parameters including number of galls, egg masses, number of females, rate of reproduction and final population of nematodes (Anwar et al., 2003; Hayat, 2011).
Keeping in view the above mentioned facts, the present study aimed at exploring the source of genotypic resistance among potato germplasm against root knot nematode (Meloidogyne incognita).

\section{MATERIALS AND METHODS}

Collection of Diseased Samples: Roots of diseased potato plants with typical symptoms of root knot nematode were collected from different potato growing areas of the Punjab province of Pakistan. Samples were collected with the help of trowel $15-20 \mathrm{~cm}$ deep from the rhizosphere of the diseased plants together with approximately $1 \mathrm{~kg}$ of adhering soil. Samples were kept in the polythene bags and moistened well to ensure the adequate moisture for nematode survival. Root samples were stored at $5^{\circ} \mathrm{C}\left(40^{\circ} \mathrm{F}\right)$ in refrigerator in Plant Nematology lab. Department of Plant Pathology, University of Agriculture Faisalabad.

\section{Isolation of Root Knot Nematodes from Roots and}

Soil: White-head and Hemming tray method (Whitehead and Hemming, 1965) was used for isolation of $M$. incognita second stage juveniles (J2) from root samples. The entire root system was cut into small pieces, chopped and composite sample of $20 \mathrm{~g}$ was placed in the tray lined with tissue paper having sufficient amount of water. After 24 hours water was poured off in a beaker and allowed to settle for one hour. Juveniles were settled down and excess water was drained off remaining the juvenile suspension.

Soil sample was thoroughly mixed and $100 \mathrm{~cm}^{3}$ composite samples was placed in plastic bucket. 1 litter of tap water was added and thoroughly mixed to break the clods. Heavy soil particles, roots and rocks were drained off from the bucket with hand. Supernatant water was poured through the coarse sieve (50-mesh) into the second bucket. A liter of water was added and the above step was repeated to get optimum number of nematodes. The water suspension was stirred and allowed to settle down. The supernatant water was then poured through fine sieve (100-mesh) to another bucket. Process was repeated using fine sieves (250 and 325-mesh). Suspension left after passing through 325-mesh sieve was transferred to $500 \mathrm{ml}$ beaker. Suspension was allowed to settle down to bottom of the beaker and access waster siphoned out suing siphon tube.

Identification of root knot nematodes: Root Knot Nematode species were identified on the basis of perineal pattern (Jepson, 1987). Visible knots on the root tissues were dissected longitudinally using sterile 
blade to detach female nematode. It was then transferred to glass slide to cut posterior half of its body. Portion containing perineal pattern was obtained, by cutting lower cuticle in a square shape, and transferred to another glass slide containing few drops of glycerin. Paraffin was used to seal the cover slip on the slide. The slide was placed under stereoscopic microscope to observe female perineal pattern to identify Meloidogyne species (Eisenback et al., 1981).

Purification of Meloidogyne incognita using single egg mass culture: From galled potato roots, egg masses of the uniform size were collected using fine forceps. These egg masses were stored in petri dishes in refrigerator at $4^{\circ} \mathrm{C}$. One month old potato seedlings were inoculated with these egg masses @ one egg mass per plant near the root zone making a hole with the help of pointed wood avoiding the root injury. The hole was covered with soil to avoid drying. Plants were watered regularly to prevent loss of nematodes through drying or leaching.

Rearing of Root Knot Nematode (M. incognita): Mass culturing of $M$. incognita was done on the roots of the susceptible potato cultivar FD-8-1 in order to get regular supply of inoculum for experiments. Potato plants were planted in $20 \mathrm{~cm}$ diameter earthen pots containing formalin sterilized sandy loam soil. Approximate of 2000 eggs of $M$. incognita in a small volume of egg suspension were pipetted around each plant by making 3-4 holes with the help of pointed wood. The holes were then covered with soil to avoid drying. Plants were watered regularly to prevent excess drying.

Soil Preparation: Sandy loam soil containing 70\% sand, $22 \%$ silt and $8 \%$ clay was thoroughly mixed and air dried by speeding in a thin layer on woody bench, covered with plastic sheet. Large stones and plant debris were removed followed by mechanical analysis of the soil.

Soil Sterilization: Soil sterilization was accomplished by the application of formalin. Formalin diluted to 1:320 ratio was added to small heap of soil. The soil was then covered with polythene sheet to stop the fumes completely. After 7 days, the soil was exposed to get rid of residual formalin. The soil was checked to ensure that there was no nematode population after sterilization. Thoroughly mixed soil was filled in the medium sized pots.

Collection of Potato Tubers: Potato seed tubers of different cultivars were collected from Vegetable Research Institute, Faisalabad and Potato Research
Institute, Sahiwal. Care was made for seed health, purity and germinating capacity.

Location of Experiment: The experiment was conducted in the research area of Department of Plant Pathology, University of Agriculture Faisalabad, Pakistan $\left(31^{\circ} 25^{\prime} 0^{\prime \prime} \mathrm{N} / 73^{\circ} 5^{\prime} 0^{\prime \prime} \mathrm{E}\right)$.

\section{Evaluation Experiments}

Counting and Standardization of Eggs: To estimate the inoculum density, nematode suspension was poured into measuring cylinder. The suspension was mixed vigorously by blowing and stirring with pipette. The numbers of nematodes were estimated in 1-ml aliquots in a counting slide under binomial stereoscopic microscope. The process was repeated three times and total population was estimated by obtaining means of the three aliquots.

Estimation of Nematode Numbers in Roots: Estimation of nematode numbers in roots was based on whole root systems. It is considered as a general practice in nematology to take (mixed) root samples for estimating the number of nematodes. However, in our study only small potted-plants, inoculated with relatively small nematode numbers were used and counting the whole sample was regarded as most accurate and reliable. Two methods were used; staining nematodes within the root system and extracting nematodes from the root system.

Estimation of nematode suspensions: When counting and estimating nematode suspensions, all samples were made up to equal volumes for a given experiment. Volumes varied from 25 to $300 \mathrm{ml}$. Samples too large in volume were left undisturbed for several hours, allowing nematodes to settle on the bottom. Water was then siphoned off until the volume was reduced to the required level. Before taking each aliquot, the suspension was agitated to ensure an even distribution of nematodes. For each suspension, several 1, 2 or $3 \mathrm{ml}$ aliquots were taken and placed in $5.5 \mathrm{~cm} \times 4 \mathrm{~cm}$ counting dishes with $2 \mathrm{~mm} \times 4 \mathrm{~mm}$ squares. For macerated root suspensions, a pipette with a wide $(2 \mathrm{~mm})$ opening was used. The number of nematodes in each aliquot was counted using stereomicroscope (Olympus SZ 61 at 6X magnifications). Estimation could thus be made of the total number of nematodes in the suspension.

Extraction method: Both Whitehead and Hemming tray and Modified Baermann trays methods were used for the extraction of $\mathrm{J} 2$ from root material (Whitehead and Hemming, 1965; Southey, 1986). These extraction 
methods are based on nematode motility. Modified Baermann extraction trays consisted of sieves made out of nylon gauze fixed onto a plastic ring $(11 \mathrm{~cm}$ diameter, $3 \mathrm{~cm}$ deep). A layer of tissue paper was placed on top of the nylon gauze onto which the root system (cut up into 1-2 cm pieces) or other material was placed. Sieves with $1.5 \mathrm{~cm}$ supports fixed onto them were placed in $17 \mathrm{~cm}$ diameter, $3 \mathrm{~cm}$ deep trays. Trays were then filled thirty six with water until material on the sieves were almost awash. Each extraction tray was covered and incubated at $25-28{ }^{\circ} \mathrm{C}$. Water was carefully added to trays when levels were low. For extraction of nematodes from root material, trays were left for 1-2 weeks and harvested for nematodes two to three times during this period. By removing the sieve from the tray and pouring off the suspension into a beaker, nematodes that migrated out of the root pieces into the water were collected. After collecting nematodes, trays were refilled with water ready for the next harvest.

Staining Methods: Acid Fuchsin and Phloxin B staining methods were used. Acid Fuchsin was used for staining nematodes within root systems and Phloxin B was used to stain M. incognita egg masses.

Extraction of $M$. incognita from Infected Seedlings: Infected roots with egg masses were washed out two weeks in advance. Plant roots with 56-63 days old egg masses were obtained in order to get maximum number of mature eggs. Roots were cut into $2-3 \mathrm{~cm}$ segments and shaken well for 3-4 minutes in $1 \mathrm{~L}$ beaker having $200 \mathrm{ml}$ of $1 \%$ sodium hypochlorite $(\mathrm{NaOCl})$ solution to dissolve the gelatinous matrix and to release eggs from the egg masses (Adegbite and Adesiyan, 2005). The suspension was poured to a series of sieves to separate the organic debris from eggs. This suspension was quickly passed through 200 -mesh $(75 \mu \mathrm{m})$ sieve nested over 500 -mesh $(25 \mu \mathrm{m})$ sieve to collect root fragments on the former and freed eggs on the latter. The eggs collected on the 500-mesh sieve were rinsed with tap water to remove the residual $\mathrm{NaOCl}$. Rinsing of eggs was done for several minutes. These freed eggs were collected in a $500 \mathrm{ml}$ beaker. This process was repeated twice to get additional eggs and to get rid of residual Chlorax and then incubated at $28{ }^{\circ} \mathrm{C}$. The hatched $\mathrm{J} 2$ were collected daily in $500 \mathrm{ml}$ beakers and labeled the date of harvesting of eggs. The age of second stage juveniles was thus known. Only freshly hatched J2 collected within $48 \mathrm{~h}$ were used for experiments (Hussey and Barker, 1973; Radewald et al., 2003).
Varietal Response of Potato Cultivars against Root Knot Nematode: Seeds of different potato cultivars were planted at $70 \mathrm{~cm}$ between row spacing and $30 \mathrm{~cm}$ within row spacing in four years sick plot containing root knot nematode ( $M$. incognita). Each treatment was replicated five times. Plants were allowed to grow for 3 months. Irrigation was done weekly throughout the period of research. Growth of the plants was observed regularly. After 90 days, plants were harvested from the field. Roots and shoots of the plants were cut, gently washed in tap water, dump-dried and weighed. Care was taken in order to limit the loss of small roots and egg masses during the washing procedure. To facilitate counting of egg masses, the washed roots were stained with phloxine B (Al-Hazmi and Sasser, 1982; Holbrook et al., 1983; Southey, 1986). Roots were placed in a phloxine B solution $(0.15 \mathrm{~g} /$ liter tap water) for about 15-20 minutes. The stain was absorbed by the gelatinous matrix, which took a pink to red color while roots remained either unstained or very lightly stained, whereas eggs remained viable. Excess stain was removed by three consecutive rinses in one liter beaker filled with water. After staining, roots were wrapped in tissue paper to prevent drying out during the steps of the procedure of evaluation. Stained egg masses from entire root system were counted under a stereomicroscope (Olympus SZ 61) at $2.5 \mathrm{X}$ magnification. The whole root system was rated for galling and egg mass presence on a 0 to 5 scale (Taylor and Sasser, 1978; Quesenberry et al., 1989; Anwar et al., 2007) where $0=$ no gall or egg masses, $1=1-2,2=3-10$, $3=11-30,4=31-100$, and $5=>100$ galls or egg masses per root system.

The data of following parameters was recorded.

- Fresh weight of root

- Fresh weight of shoot

- Number of galls/root system

- Nematode reproduction factor [Pf/Pi, where Pf $=$ final nematode population at harvest, $\mathrm{Pi}=$ initial inoculum].

- Galling index

- Number of egg masses

Grouping of varieties according to level of their resistance or susceptibility was done.

Statistical Analysis: Complete randomized design was used in controlled laboratory conditions and Randomized Complete Block Design was used in the field conditions. SAS Statistical software was used for 
the analysis of variance and computing probability (less than 0.05) of the recorded data. Duncan's multiple range tests was used to determine the most significant treatment (Steel et al., 1997).

\section{RESULTS AND DISCUSSION}

All thirty seven potato cultivars varied widely in their susceptibility to $M$. incognita infection $(\mathrm{P}<0.05)$. This experiment was aimed at to evaluate the genotypic response of thirty six potato cultivars against $M$. incognita as a resistance source for root knot nematode management. Comparison of all these cultivars was accessed on the basis of plant growth parameters (number of leaves per plant, average weight of each tuber, root weight per plant and shoot weight per plant) and nematode reproduction parameters (root galls and egg mass indices, number of nematodes per root system, number nematodes/ $100 \mathrm{ml}$ of soil and nematode reproduction factor).

Comparison among different potato cultivars on the basis of plant growth parameters

Effect of Meloidogyne incognita infection on number of leaves:

Each potato cultivar responded differently to root knot nematode (Meloidogyne incognita) infection. There is a significant difference between numbers of leaves of each plant. Cultivar FD-49-62 had statistically $(\mathrm{P}<0.05)$ more number of leaves (75.2) as compared to all other cultivars. FD-1-3, FD-35-25 and FD-53-1 had statistically same number of leaves. Minimum numbers of leaves (29.2) were found in Cardinal followed by FSDWhite (30.4) and N-9619 (30.4).

Effect of Meloidogyne incognita infection on average tuber weight: Average tuber weight of each potato cultivar was significantly $(\mathrm{P}<0.05)$ different. FD-49-62 had statistically high tuber weight ( $90.6 \mathrm{~g}$ ) as compared all other tested cultivars. FD-1-3 and SSH-339 had statistically same tuber weight $(62.3$ and $61.6 \mathrm{~g}$ respectively) higher than that of SH-332 (46.6 g) and FD-51-5 (45.0 g). All other cultivars had statistically low tuber weight due to $M$. incognita infection. Minimum tuber weight was recorded in FD-19-2 (12.0 g) followed by SH-692, FD-8-1 (17.3 g) and SH-5 (23.3 g).

Effect of Meloidogyne incognita infection on root weight: FD-49-62 had significantly $(\mathrm{P}<0.05)$ less root weight (7.973 g) followed by SH-339, SH-332 and FD-13 who had statistically same root weight $(8.423,8.473$ and $8.523 \mathrm{~g}$ respectively). All other potato cultivars tested against root knot nematode (Meloidogyne incognita) infection had statistically more root weight.
Maximum root weight was recorded in FD-8-1 (13.813 g) followed by FD-19-2 (13.783 g) and SH-692 (13.443 g). FD-21-10 (12.873 g) and SH-5 (12.843 g) had statistically same root weight higher than FD-69-1 (12.683 g), SH-216 (12.543 g) and lower than SH-5 potato cultivar.

Effect of Meloidogyne incognita infection on shoot weight: Statistically $(P>0.05)$ maximum shoot weight (29.87 g) was recorded in FD-8-3 followed by FD-19-2 (29.46 g), Cardinal (28.13 g), N-22 (27.74 g) and SH-5 (26.96 g). All other cultivars had statistically low shoot weight as compared to these cultivars. Minimum shoot weight (17.9 g) was recorded in FD-49-28. FD-35-1 and SH-339 had statistically same shoot weight (18.61 and 18.60 g respectively).

Comparison among different potato cultivars on the basis of nematode reproduction parameters Effect of Meloidogyne incognita infection on root galls development: Root knot nematode (M. incognita) produced galls on the roots of all thirty six cultivars. Data regarding root galls/root system as shown in Table 2. revealed that statistically $(\mathrm{P}<0.05)$ maximum number of galls (44.0) were found on FD-19-2 followed by FD-81 (43.33), SH-692 (43.0) and SH-5 (41.33). Statistically same numbers of galls (39.33) were produced on FD35-25 FD-52-2 and FD-35-36. Minimum numbers of galls (17) were recorded in FD-49-62 followed by FD-13 (18), SH-339 (18.667), SH-704 (19.33) and SH-332 (21.0).

Effect of Meloidogyne incognita infection on egg mass development: Data regarding egg mass production revealed that there is significant difference in nematode egg mass production on the roots of each cultivar tested against root knot nematode (M. incognita) infection. Statistically $(\mathrm{P}>0.05)$ maximum numbers of egg masses (77.0) were produced of FD-19-2 followed by SH-692 (75.6), FD-8-1 (73.3) and SH-5 (68.66). FD-1-3 exhibit minimum number of egg masses (23.3) as compared to all other cultivars. FD-75-3 had number of galls (24.6) followed by FD-49-62, (25.66), FD-51-5 (26.0) and FD-53-1 (29.0).

Effect of Meloidogyne incognita infection on nematode population per root system: Nematode population per root system recorded after harvesting revealed that statistically $(\mathrm{P}<0.05)$ maximum numbers of nematodes per root system (2607.8) were recorded in FD-19-2 followed by FD-69-1 (2317.5), FD-8-1 (2310) and SH-692 (2250.1). All other cultivars had lower number of nematodes as compared to these cultivars. 
Table 1. Effect of Meloidogyne incognita infection on plant growth parameters.

\begin{tabular}{|c|c|c|c|c|}
\hline Cultivar & No. of Leaves & Tuber weight & Root Weight & Shoot Weight \\
\hline Cardinal & $66.565 \pm 1.15 \mathrm{~B}$ & $45.00 \pm 0.82 \mathrm{D}$ & $8.92 \pm 0.58 \mathrm{NOP}$ & $26.97 \pm 0.44 \mathrm{E}$ \\
\hline FD-1-3 & $66.872 \pm 0.33 \mathrm{~B}$ & $62.33 \pm 1.47 \mathrm{~B}$ & $8.52 \pm 1.32 \mathrm{OPQ}$ & $29.47 \pm 0.44 \mathrm{~B}$ \\
\hline FD-19-2 & $33.249 \pm 0.37 \mathrm{~T}$ & $17.00 \pm 0.82 \mathrm{~T}$ & $13.78 \pm 0.58 \mathrm{AB}$ & $17.91 \pm 0.37 \mathrm{~T}$ \\
\hline FD-21-10 & $45.458 \pm 0.35 \mathrm{R}$ & $24.33 \pm 0.78 \mathrm{R}$ & $12.87 \pm 0.73 \mathrm{BC}$ & $19.63 \pm 0.44 \mathrm{PQ}$ \\
\hline FD-35-1 & $62.366 \pm 0.37 \mathrm{DEFG}$ & $36.67 \pm 0.82 \mathrm{H}$ & $9.51 \pm 0.58 \mathrm{MN}$ & $25.92 \pm 0.61 G$ \\
\hline FD-35-25 & $54.238 \pm 0.35 \mathrm{MNO}$ & $32.33 \pm 0.78 \mathrm{M}$ & $10.45 \pm 0.73 \mathrm{IJKL}$ & $22.16 \pm 0.53 \mathrm{~K}$ \\
\hline FD-35-36 & $49.14 \pm 0.33 \mathrm{P}$ & $29.00 \pm 1.47 \mathrm{NO}$ & $11.70 \pm 1.32 \mathrm{EF}$ & $21.21 \pm 0.53 \mathrm{LM}$ \\
\hline FD-49-28 & $62.147 \pm 0.37 \mathrm{EFG}$ & $35.33 \pm 0.82 \mathrm{IJ}$ & $9.48 \pm 0.58 \mathrm{MN}$ & $25.30 \pm 0.37 \mathrm{H}$ \\
\hline FD-49-62 & $75.912 \pm 0.35 \mathrm{~A}$ & $84.67 \pm 0.78 \mathrm{~A}$ & $7.97 \pm 0.73 \mathrm{Q}$ & $29.87 \pm 0.53 \mathrm{~A}$ \\
\hline FD-51-5 & $47.057 \pm 0.35 \mathrm{QR}$ & $26.67 \pm 0.78 \mathrm{PQ}$ & $11.81 \pm 0.73 \mathrm{DEF}$ & $20.90 \pm 0.37 \mathrm{~N}$ \\
\hline FD-5-2 & $48.0450 .70 \mathrm{PQ}$ & $27.00 \pm 0.82 \mathrm{P}$ & $11.62 \pm 0.58 \mathrm{FG}$ & $21.10 \pm 0.44 \mathrm{MN}$ \\
\hline FD-52-7 & $62.9 \pm 1.93 \mathrm{CDEF}$ & $36.00 \pm 1.47 \mathrm{HI}$ & $9.70 \pm 1.32 \mathrm{KLMN}$ & $25.87 \pm 0.44 \mathrm{G}$ \\
\hline FD-53-1 & $64.113 \pm 1.42 \mathrm{CD}$ & $42.00 \pm 0.82 \mathrm{EF}$ & $9.42 \pm 0.58 \mathrm{MNO}$ & $26.46 \pm 0.53 \mathrm{~F}$ \\
\hline FD-53-2 & $48.92 \pm 0.71 \mathrm{P}$ & $28.67 \pm 0.780$ & $11.45 \pm 0.73 \mathrm{FGH}$ & $21.20 \pm 0.61 \mathrm{LM}$ \\
\hline FD-53-6 & $57.344 \pm 1.05 \mathrm{JK}$ & $33.33 \pm 1.47 \mathrm{KLM}$ & $10.30 \pm 1.32 \mathrm{IJKLM}$ & $23.58 \pm 0.61 \mathrm{I}$ \\
\hline FD-69-1 & $46.495 \pm 0.50 \mathrm{QR}$ & $25.67 \pm 0.82 Q$ & $12.68 \pm 0.58 \mathrm{CD}$ & $19.86 \pm 0.53 \mathrm{P}$ \\
\hline FD-69-2 & $60.92 \pm 0.77 \mathrm{GH}$ & $34.00 \pm 1.47 \mathrm{~K}$ & $9.90 \pm 1.32 \mathrm{JKLM}$ & $25.22 \pm 0.53 \mathrm{H}$ \\
\hline FD-70-1 & $55.388 \pm 1.27 \mathrm{LMN}$ & $32.67 \pm 0.78 \mathrm{LM}$ & $10.54 \pm 0.73 \mathrm{HIJK}$ & $22.18 \pm 0.44 \mathrm{~K}$ \\
\hline FD-75-3 & $63.325 \pm 0.91 \mathrm{CDE}$ & $41.33 \pm 0.78 \mathrm{~F}$ & $9.47 \pm 0.73 \mathrm{MN}$ & $26.44 \pm 0.44 \mathrm{~F}$ \\
\hline FD-76-35 & $63.555 \pm 0.60 \mathrm{CDE}$ & $40.00 \pm 1.47 \mathrm{G}$ & $9.65 \pm 1.32 \mathrm{KLMN}$ & $26.22 \pm 0.37 \mathrm{~F}$ \\
\hline FD-8-1 & $30.194 \pm 0.96 \mathrm{U}$ & $20.33 \pm 1.47 \mathrm{~S}$ & $13.81 \pm 1.32 \mathrm{~A}$ & $18.19 \pm 0.44 \mathrm{~S}$ \\
\hline FD-8-3 & $53.88 \pm 1.32 \mathrm{NO}$ & $30.00 \pm 1.47 \mathrm{~N}$ & $10.77 \pm 1.32 \mathrm{GHIJ}$ & $22.13 \pm 0.44 \mathrm{~K}$ \\
\hline FSD-White & $57.457 \pm 0.60 \mathrm{JK}$ & $33.33 \pm 0.78 \mathrm{KLM}$ & $9.91 \pm 0.73 \mathrm{JKLM}$ & $25.11 \pm 0.37 \mathrm{H}$ \\
\hline $\mathrm{N}-2002-1$ & $63.597 \pm 1.01 \mathrm{CDE}$ & $36.33 \pm 0.78 \mathrm{HI}$ & $9.59 \pm 0.73 \mathrm{LMN}$ & $25.88 \pm 0.53 G$ \\
\hline $\mathrm{N}-22$ & $61.406 \pm 0.50 \mathrm{FG}$ & $34.33 \pm 0.78 \mathrm{JK}$ & $9.70 \pm 0.73 \mathrm{KLMN}$ & $25.24 \pm 0.61 \mathrm{H}$ \\
\hline $\mathrm{N}-30$ & $55.912 \pm 0.56 \mathrm{KLM}$ & $32.67 \pm 0.82 \mathrm{LM}$ & $10.51 \pm 0.58 \mathrm{IJK}$ & $\begin{array}{c}23.20 \pm 0.61 \mathrm{~J} \\
\text { Cont } \ldots\end{array}$ \\
\hline
\end{tabular}




\begin{tabular}{|c|c|c|c|c|}
\hline Cultivar & No. of Leaves & Tuber weight & Root Weight & Shoot Weight \\
\hline N-9619 & $58.292 \pm 0.84 \mathrm{IJ}$ & $33.33 \pm 0.82$ KLM & $10.22 \pm 0.58 \mathrm{IJKLM}$ & $25.12 \pm 0.53 \mathrm{H}$ \\
\hline SH-216 & $47.034 \pm 0.87 \mathrm{QR}$ & $26.33 \pm 1.47 \mathrm{PQ}$ & $12.54 \pm 1.32 \mathrm{CDE}$ & $20.30 \pm 0.610$ \\
\hline SH-278 & $56.15 \pm 0.52 \mathrm{KL}$ & $32.67 \pm 1.47 \mathrm{LM}$ & $10.77 \pm 1.32 \mathrm{GHIJ}$ & $23.48 \pm 0.37 \mathrm{I}$ \\
\hline SH-332 & $66.96 \pm 0.81 \mathrm{~B}$ & $46.67 \pm 0.78 \mathrm{C}$ & $8.47 \pm 0.73 \mathrm{PQ}$ & $27.75 \pm 0.61 \mathrm{D}$ \\
\hline SH-339 & $67.64 \pm 1.35 \mathrm{~B}$ & $61.67 \pm 0.82 \mathrm{~B}$ & $8.42 \pm 0.58 \mathrm{PQ}$ & $28.14 \pm 0.37 \mathrm{C}$ \\
\hline $\mathrm{SH}-479$ & $53.014 \pm 0.910$ & $29.67 \pm 0.82 \mathrm{NO}$ & $10.96 \pm 0.58 \mathrm{FGHI}$ & $21.47 \pm 0.37 \mathrm{~L}$ \\
\hline $\mathrm{SH}-5$ & $43.19 \pm 1.00 \mathrm{~S}$ & $23.33 \pm 1.47 \mathrm{R}$ & $12.84 \pm 1.32 \mathrm{C}$ & $19.55 \pm 0.37 \mathrm{Q}$ \\
\hline SH-692 & $31.298 \pm 0.49 \mathrm{U}$ & $20.33 \pm 0.78 \mathrm{~S}$ & $13.44 \pm 0.73 \mathrm{ABC}$ & $18.61 \pm 0.53 R$ \\
\hline SH-701 & $59.545 \pm 0.74 \mathrm{HI}$ & $33.67 \pm 0.82 \mathrm{KL}$ & $9.72 \pm 0.58 \mathrm{KLMN}$ & $25.16 \pm 0.44 \mathrm{H}$ \\
\hline SH-704 & $64.369 \pm 1.37 \mathrm{C}$ & $43.00 \pm 1.47 \mathrm{E}$ & $9.41 \pm 1.32 \mathrm{MNO}$ & $26.49 \pm 0.61 \mathrm{~F}$ \\
\hline LSD & 3.0465 & 1.0648 & 0.9176 & 0.2780 \\
\hline
\end{tabular}

Means sharing same letters are not significantly different from each other at $\mathrm{P}=0.05$.

Table 2. Effect of Meloidogyne incognita infection on nematode reproduction parameters.

\begin{tabular}{lllll}
\hline Cultivar & Number of Galls & Egg Masses & $\begin{array}{c}\text { Nematode Population/ } \\
\text { Root System }\end{array}$ & Reproduction Factor** \\
\hline Cardinal & $21.00 \pm 0.84 \mathrm{~T}$ & $29.00 \pm 1.00 \mathrm{Z}$ & $2230.60 \pm 11.35 \mathrm{CD}$ & $1.74 \pm 0.01 \mathrm{a}$ \\
FD-1-3 & $19.33 \pm 0.59 \mathrm{U}$ & $24.67 \pm 0.73 \mathrm{~b}$ & $2250.10 \pm 20.46 \mathrm{C}$ & $1.58 \pm 0.01 \mathrm{~b}$ \\
FD-19-2 & $43.00 \pm 0.43 \mathrm{~B}$ & $77.00 \pm 0.59 \mathrm{~A}$ & $726.80 \pm 10.14 \mathrm{U}$ & $5.38 \pm 0.01 \mathrm{~A}$ \\
FD-21-10 & $41.33 \pm 0.38 \mathrm{C}$ & $67.67 \pm 0.77 \mathrm{E}$ & $736.30 \pm 17.76 \mathrm{U}$ & $4.17 \pm 0.02 \mathrm{E}$ \\
FD-35-1 & $29.67 \pm 0.84 \mathrm{~N}$ & $35.00 \pm 1.00 \mathrm{VW}$ & $1884.80 \pm 21.34 \mathrm{G}$ & $1.92 \pm 0.01 \mathrm{VW} *$ \\
FD-35-25 & $39.00 \pm 0.55 \mathrm{G}$ & $51.67 \pm 0.95 \mathrm{~N}$ & $1010.80 \pm 18.80 \mathrm{NO}$ & $3.21 \pm 0.03 \mathrm{~L}$ \\
FD-35-36 & $39.67 \pm 0.59 \mathrm{EF}$ & $57.33 \pm 0.73 \mathrm{~K}$ & $896.30 \pm 21.36 \mathrm{~S}$ & $3.88 \pm 0.02 \mathrm{~J}$ \\
FD-49-28 & $30.33 \pm 0.43 \mathrm{M}$ & $37.00 \pm 0.59 \mathrm{~T}$ & $1994.50 \pm 10.14 \mathrm{~F}$ & $2.01 \pm 0.01 \mathrm{~T}$ \\
FD-49-62 & $17.00 \pm 0.38 \mathrm{X}$ & $23.33 \pm 0.77 \mathrm{c}$ & $2607.80 \pm 12.91 \mathrm{~A}$ & $1.48 \pm 0.03 \mathrm{c}$ \\
FD-51-5 & $40.00 \pm 0.55 \mathrm{E}$ & $62.33 \pm 0.95 \mathrm{H}$ & $883.80 \pm 17.02 \mathrm{~S}$ & $4.00 \pm 0.02 \mathrm{H}$ \\
FD-5-2 & $40.00 \pm 0.56 \mathrm{E}$ & $61.67 \pm 0.71 \mathrm{I}$ & $896.80 \pm 11.35 \mathrm{~S}$ & $3.98 \pm 0.01 \mathrm{HI}$ \\
FD-52-7 & $28.00 \pm 0.59 \mathrm{O}$ & $36.33 \pm 0.73 \mathrm{U}$ & $1554.70 \pm 20.46 \mathrm{I}$ & $1.95 \pm 0.01 \mathrm{U}$ \\
FD-53-1 & $24.00 \pm 0.43 \mathrm{R}$ & $30.67 \pm 0.59 \mathrm{Y}$ & $2069.50 \pm 12.91 \mathrm{E}$ & $1.86 \pm 0.02 \mathrm{Y}$
\end{tabular}




\begin{tabular}{|c|c|c|c|c|}
\hline Cultivar & Number of Galls & Egg Masses & $\begin{array}{c}\text { Nematode Population/ } \\
\text { Root System }\end{array}$ & Reproduction Factor** \\
\hline FD-53-2 & $40.00 \pm 0.38 \mathrm{E}$ & $58.33 \pm 0.77 \mathrm{~J}$ & $939.80 \pm 25.34 \mathrm{R}$ & $3.97 \pm 0.02 \mathrm{I}$ \\
\hline FD-53-6 & $36.00 \pm 0.83 \mathrm{I}$ & $46.00 \pm 0.96 \mathrm{P}$ & $1011.30 \pm 27.30 \mathrm{~N}$ & $2.25 \pm 0.01 \mathrm{P}$ \\
\hline FD-69-1 & $41.00 \pm 0.56 \mathrm{CD}$ & $65.00 \pm 0.71 \mathrm{~F}$ & $830.30 \pm 12.91 \mathrm{~T}$ & $4.13 \pm 0.02 \mathrm{~F}$ \\
\hline FD-69-2 & $31.33 \pm 0.59 \mathrm{~L}$ & $38.67 \pm 0.73 \mathrm{~S}$ & $1228.10 \pm 21.36 \mathrm{~K}$ & $2.11 \pm 0.02 \mathrm{R}$ \\
\hline FD-70-1 & $39.00 \pm 0.43 \mathrm{G}$ & $48.33 \pm 0.820$ & $998.10 \pm 17.76$ NOP & $2.70 \pm 0.02 \mathrm{M}$ \\
\hline FD-75-3 & $27.67 \pm 0.380$ & $34.00 \pm 0.77 X$ & $2061.50 \pm 17.76 \mathrm{E}$ & $1.90 \pm 0.02 \mathrm{X}$ \\
\hline FD-76-35 & $26.67 \pm 0.83 \mathrm{P}$ & $34.67 \pm 0.96 \mathrm{~W}$ & $1849.00 \pm 19.81 \mathrm{H}$ & $1.91 \pm 0.01 \mathrm{WX}$ \\
\hline FD-8-1 & $44.00 \pm 0.54 \mathrm{~A}$ & $75.67 \pm 0.68 \mathrm{~B}$ & $697.80 \pm 20.46 \mathrm{~V}$ & $4.82 \pm 0.01 \mathrm{~B}$ \\
\hline FD-8-3 & $39.33 \pm 0.59 \mathrm{FG}$ & $52.67 \pm 0.73 \mathrm{M}$ & $991.30 \pm 20.46 \mathrm{OP}$ & $3.27 \pm 0.01 \mathrm{~K}$ \\
\hline FSD-White & $33.00 \pm 0.43 \mathrm{~J}$ & $42.00 \pm 0.82 Q$ & $1181.30 \pm 17.02 \mathrm{~L}$ & $2.16 \pm 0.02 \mathrm{Q}$ \\
\hline $\mathrm{N}-2002-1$ & $25.00 \pm 0.38 Q$ & $35.33 \pm 0.77 \mathrm{~V}$ & $1871.10 \pm 18.80 \mathrm{G}$ & $1.94 \pm 0.03 \mathrm{UV}$ \\
\hline $\mathrm{N}-22$ & $31.00 \pm 0.84 \mathrm{~L}$ & $38.33 \pm 1.23 \mathrm{~S}$ & $1536.30 \pm 25.34 \mathrm{I}$ & $2.04 \pm 0.02 \mathrm{~S}$ \\
\hline $\mathrm{N}-30$ & $38.00 \pm 0.56 \mathrm{H}$ & $46.33 \pm 0.71 \mathrm{P}$ & $1004.30 \pm 21.34 \mathrm{NO}$ & $2.60 \pm 0.01 \mathrm{~N}$ \\
\hline $\mathrm{N}-9619$ & $32.00 \pm 0.61 \mathrm{~K}$ & $41.67 \pm 0.76 \mathrm{Q}$ & $1056.30 \pm 12.91 \mathrm{M}$ & $2.13 \pm 0.02 \mathrm{R}$ \\
\hline SH-216 & $40.67 \pm 0.42 \mathrm{D}$ & $64.00 \pm 0.55 \mathrm{G}$ & $881.30 \pm 27.30 \mathrm{~S}$ & $4.08 \pm 0.01 \mathrm{G}$ \\
\hline SH-278 & $38.00 \pm 0.37 \mathrm{H}$ & $46.00 \pm 0.51 \mathrm{P}$ & $981.80 \pm 19.81 \mathrm{PQ}$ & $2.47 \pm 0.010$ \\
\hline SH-332 & $18.67 \pm 0.84 \mathrm{~V}$ & $26.00 \pm 1.23 \mathrm{a}$ & $2310.00 \pm 25.34 \mathrm{~B}$ & $1.59 \pm 0.02 b$ \\
\hline SH-339 & $18.00 \pm 0.56 \mathrm{~W}$ & $25.67 \pm 0.71 \mathrm{a}$ & $2317.50 \pm 10.14 \mathrm{~B}$ & $1.58 \pm 0.01 \mathrm{~b}$ \\
\hline SH-479 & $39.33 \pm 0.61 \mathrm{FG}$ & $54.00 \pm 0.76 \mathrm{~L}$ & $969.30 \pm 10.14 \mathrm{Q}$ & $3.86 \pm 0.01 \mathrm{~J}$ \\
\hline SH-5 & $41.33 \pm 0.42 \mathrm{C}$ & $68.67 \pm 0.55 \mathrm{D}$ & $739.30 \pm 19.81 \mathrm{U}$ & $4.29 \pm 0.01 \mathrm{D}$ \\
\hline SH-692 & $43.33 \pm 0.38 \mathrm{~B}$ & $73.33 \pm 0.77 \mathrm{C}$ & $736.30 \pm 18.80 \mathrm{U}$ & $4.67 \pm 0.03 \mathrm{C}$ \\
\hline SH-701 & $32.00 \pm 0.84 \mathrm{~K}$ & $40.67 \pm 1.00 \mathrm{R}$ & $1270.00 \pm 11.35 \mathrm{~J}$ & $2.12 \pm 0.01 \mathrm{R}$ \\
\hline SH-704 & $22.67 \pm 0.54 \mathrm{~S}$ & $30.33 \pm 0.68 \mathrm{Y}$ & $2220.80 \pm 27.30 \mathrm{D}$ & $1.83 \pm 0.01 \mathrm{Z}$ \\
\hline LSD & 0.5344 & 0.5724 & 19.608 & 0.0201 \\
\hline
\end{tabular}

Means sharing same letters are not significantly different from each other at $\mathrm{P}=0.05$ 
Minimum number of nematodes were recorded in FD49-62 (697.8) followed by FD-1-3 (726.8), FD-51-5 \& SH-332 (736.3) and SH-339 (739.3).

Effect of Meloidogyne incognita infection on nematode reproduction factor: Data regarding nematode reproduction factor on each cultivar (Table 2) revealed that there is significant difference between nematode reproduction factors on each potato cultivar. FD-49-62 exhibit high nematode reproduction factor followed by FD-1-3, SH-339 and SH-332. Magnitude of nematode reproduction factor (5.83) was high FD-19-2 followed by FD-8-1 (4.81), SH-692 (4.67) and SH-5 (4.29).

Root knot nematodes are the most damaging group of plant parasitic nematodes associated with vegetable crops occurring throughout the world. The areas having sandy loam and loam soil type has more root knot nematode (M. incognita). Soil type is an important factor affecting nematode movement, growth and reproduction rate and host suitability (Starr et al., 1993; Ogbuji, 2004; Anwar et al., 2007).

Root knot nematode (M. incognita) the hidden enemies are causing significant yield losses by attacking on the root systems of the susceptible host plant. Primary symptom of Meloidogyne incognita infection is the formation of root galls on the roots of susceptible host plants. Flow of water and nutrients into the plants is greatly influenced by nematode feeding that leads to the reduced yield of the agricultural crops (Roberts, 1987; Sikora and Fernandez, 1990). In addition to nematode infestations, plants with damaged roots become susceptible to other disease causing agents and stress factors including heat, water and nutritional deficiencies (Powell, 1971; Anwar and Din, 1986; Khan et al., 2007).

Genotypic/ Varietal response of thirty six different potato cultivars to root knot nematode (M. incognita) infection evaluated on the basis of plant growth parameters (number of levees per plant, average tuber weight of each cultivar, root weight per plant and shoot weight per plant) and nematode reproduction parameters (root galls and egg mass indices, number of nematodes per root system, number of nematodes per $100 \mathrm{ml}$ of soil and nematode reproduction parameter was) was considerably variable among cultivars.

There was not a single cultivar immune to root knot nematode (M. incognita) infection. Susceptibility of different vegetable crops and potato cultivars had already been reported by different scientists (Khan et al., 2006; Abbas et al., 2008; Kamran, 2008; Sahi, 2008;
Ubaid, 2009 and Hayat et al., 2012). Results of the present studies were different from Shahzad et al., 1999 and Darban et al., 2003.

Among different potato cultivars tested against root knot nematode ( $M$. incognita) infection, pronounced variation has been observed. The variation of the cultivars to nematode infection might be attributed to their genetic makeup and level of resistance mechanism possessed by a particular cultivar (Barham and Winstead, 1957; Anwar and Mckenry, 2002 and Abad et al., 2003).

Status of the host plant to the nematode infection can be assessed by the number of root galls produced by the root systems of the host plants, nematode reproduction and the final nematode population per gram of root or soil at the time of harvest (Gast et al., 1984; Belair and Benoit, 1996 and Davis et al., 2003). The magnitude of nematode reproduction factor $(\mathrm{P} f / \mathrm{P} i=$ nematode final population over initial population) to determine host status is considered to be more accurate measure of nematode-host relationship (Anwar et al., 2000). Cultivar resistance to plant parasitic nematode infection can also be evaluated on the basis on root galls and egg mass numbers (Hussey and Boerma, 1981).

The reliability among potato cultivars in terms of root galls and egg mass indices propose that it is convenient and better intimation of resistance against root knot nematode (M. incognita) (Luzzi et al., 1987). These intimations can only be used for preliminary evaluation of the resistance of cultivars against root knot nematode (M. incognita) infection and the concluding estimation must be based on the nematode reproduction (Hussey and Janssen, 2004).

All thirty seven cultivars found susceptible because they had root galls and egg mas indices $>3$ and rate of reproduction $>1$. Similar results of root galls, egg mass indices and nematode reproduction rate have also been reported (Hayat, 2011). The amount of eggs laid by female nematodes are influenced by environmental conditions and host status to a particular nematode species or populations (Luc et al., 2005; Ashoub and Amara, 2010).

\section{CONCLUSION}

Among different potato cultivars tested against rot knot nematode (M. incognita) FD-19-2, FD-8-1, SH-292, SH5and FD69-1 exhibit high root galls, egg mass indices and nematode reproduction factor and found highly susceptible to root knot nematode infection. Magnitude of nematode reproduction factor, root galls and egg 
mass indices were less in FD-49-62, FD-1-3, SH-339, SH332 cultivars.

\section{REFERENCES}

Abad, P., B. Favery, M. N. Rosso and P. C. Sereno. 2003 Root knot nematode parasitism and host response; molecular basis of a sophisticated interaction. Mol. Pl. Pathol. 4: 217-224.

Abbas, W., S.A. Anwar, A. Zia and N. Javed. 2008. Response of four tomato cultivars to Meloidogyne incognita infection and its chemical management. Pak. J. Nematol. 26: 3743.

Adegbite, A.A. and S.O. Adesiyan. 2005. Root extracts of plants to control root knot nematodes on edible soybean. World. J. Agri. Sci.1: 18-21.

Agrios, G.N. 2005. Plant Pathology (5th edition). Elsevier-Academic Press. San Diego, CA.

Ahmad, H., N. Javed, S.A. Khan, A.S. Gondal and H.U. Khan. 2012. Effect of organic amendments on nematode galling index and egg masses production in potato inoculated with root knot nematode. Pak. J. Phytopathol. 24: 01-05.

Al-Hazmi, A.S. and J.N. Sasser. 1982. Biology of Meloidogyne platani Hirschmann parasitic on sycamore, Platanus occidentalis. J. Nematol. 14: 154-161.

Amin, B. 2003. Evaluation of tomato cultivars for resistance to different inoculum levels of root knot nematodes (Meloidogyne incognita). M.Sc. Thesis. Dept. Pl. Pathol. Univ. of Agri., Faisalabad, Pakistan.

Anwar, S.A., A. ZIA, M. Hussain, M. Kamran. 2007. Host suitability of selected plants to Meloidogyne incognita in the Punjab, Pakistan. Int. J. Nematol., 17:144-150.

Anwar, S.A. 1996. Invasion and development of Meloidogyne incognita on various host crops. Pak. J. Phytopathol. 8: 119-126.

Anwar, S.A. and G.M. Din. 1986. Nematodes: Biotic constrains to plant health. Proc. Parasitol. 3: 4853.

Anwar, S.A. and M.V. McKenry. 2002. Developmental response of a resistance-breaking population of Meloidogyne arenaria on Vitis spp. J. Nematol., 34: 28-33.

Anwar, S.A. and M.V. McKenry. 2010. Incidence and reproduction of Meloidogyne incognita on vegetable crop Genotype. Pak. J. Zool. 42: 135141.

Anwar, S.A., M.C. McKenry and N. Javad. 2006. The rootknot nematodes: destructive pests of crops. p. 216-222. Proceedings of International Symposium on Sustainable Crop Improvement and Integrated Management. September 14-16,
2006. Faculty of Agri., Univ. of Agri., Faisalabad, Pakistan.

Anwar, S.A., M.V. McKenry, K.Y. Yoel and A.J. Anderson. 2003. Induction of tolerance to root-knot nematode by $0 x y$ com $^{\text {TM }}$ J. Nematol. 35: 306-313.

Anwar, S.A., M.V. McKenry and J. Faddoul. 2000. Reproductive variability of field populations of Meloidogyne spp. On grape rootstocks. J. Nematol. 32: 265-270.

Anwar, S.A., S. Gorsi, M.A. Haq, T. Rehman and P. Yousuf. 1991. Plant parasitic nematodes of some field, vegetable, fruit and ornamental crops. J. Agri. Res. 29:233-249.

Arooj, M. 2011. Infection of root knot nematode (Meloidogyne incognita) on medicinal plants and its biological management. M.Sc. Thesis. Dept. of Pl. Pathol. Univ. of Agri., Faisalabad, Pakistan.

Ashiq, A., R.M. Ahmad, A. Iqbal, N.Javed and N.A. Khan. 2004. Screening of soybean cultivars against root-knot nematode (Meloidogyne incognita Kofoid \& White) Chitwoodi. Pak. J. Phytopathol. 16: 66-68.

Ashoub, A.H. and M.J Amara. 2010. A review of mangrove value and conservation strategy by local communities in Hormozgan. American Sci. 6: 321-328.

Barham, W.S. and N.W. Winstead. 1957. Inheritance of resistance to root knot nematodes in tomatoes. Proc. Amer. Soc. Hort. Sci. 69:372-377.

Belair, G. and D.L. Benoit. 1996. Host suitability of 32 common weeds to Meloidogyne hapla in organic soils of southwestern Quebec. J. Nematol. 28: 643-647.

Bourne, J.M., P.K. Karanja, H. Kalisz, D.K. Karanja, T.H. Mauchline and B.R. Kerry, 2004. Incidence and severity of damage caused by Meloidogyne spp. and isolation and screening of the nematophagous fungus Pochonia chlamydosporia from some of the main vegetable growing areas in Kenya. Int. J. Nematol., 14: 111-120.

Cetintas, R., M.M. Yarba. 2010. Nematicidal effects of five essential plant oils on the southern root-knot nematode, Meloidogyne incognita Race 2. J. Anim. Vet. Adv. 9: 222-225.

Darban, D.A., S.R. Gowen, B. Pembroke, A.N. Mahar. 2003. Development of Pasteuria penetrans in Meloidogyne javanica females as affected by constantly high vs fluctuating temperature in an in vivo system. J. Zhejiang Univ. 6: 155-157.

Das, J. and A. K. Das. 2000. Prevalence of root knot nematodes on vegetable crops in Aasam and Arunachal Pradesh. Ind. J. of Nematol. 30: 244245. 
Davis, R.F., H.J. Earl and P. Timper. 2003. Interaction of root -knot nematode stress and water stress in cotton. Univ. of Georgia Cotton Research and Extension Report. 312-315.

Eisenback, J.D., H. Hirschmann., J.N. Sasser and A.C. Triantaphyllou. 1981. A guide to the four most common species of root knot nematodes, Meloidogyne spp. with a pictorial key. North Carolina State Uni. Graphics and USAID, Raleigh. 48-48.

Gast, R.E., R.G. Wilson and E.D. Kerr. 1984. Lesion nematode (Pratylenchus spp.) infection of weeds species and field beans (Phaseolus vulgaris). Weed Sci. 32: 616-620.

Gowen, S.R., T.K. Ruabete and J.G. Wright. 2005. Plant protection service secretariat of the Pacific Community Pest Advisory, Leaflet No. 9: 1-4.

Haase, N.U. 2008. The canon of potato science: 50 . The nutritional value of potatoes. Potato Res., 50: 415-417.

Hayat, A. 2011. Screening of potato cultivars against root knot nematode (Meloidogyne incognita) and its management through organic amendments. M.Sc. Thesis. Dept. of Pl. Pathol. Univ. of Agri., Faisalabad, Pakistan.

Holbrook, C.C., D.A. Knauft and D.W. Dickson. 1983. A technique for screening peanut for resistance to Meloidogyne arenaria. Pl. Dis. 67:957-958.

Hollis, F.P. 1963. Action of plant parasitic nematodes on their host. Nematologica. 9: 475-496.

Hussey, R.S. and H.R. Boerma. 1981. A greenhouse screening procedure for root-knot nematode resistance in soybeans. Crop Sci. 21:794-796.

Hussey, R.S. and K.R. Barker. 1973. A comparison of methods of collecting inocula of Meloidogyne spp., including a new technique. Plant Disease Reporter. 57: 1025-1028.

Hussey, R.S., G.J.W. Janssen. 2004. Root-knot Nematode: Meloidogyne Species. In: Starr JL, Cook R, Bridge J, editors. Plant Resistance to Parasitic Nematodes. New York: CABI Publishing. 43-70.

Jepson, S.B. 1987. Identification of root-knot nematodes (Meloidogyne species). Wallingford, UK, CAB International.

Kamran, M. 2008. Occurrence and response of root-knot nematodes with tomato (Lycopersicon esculentum M.) and its distribution in Sargodha district. M.Sc. Thesis Dept. Pl. Pathol. Univ. Agri., Faisalabad, Pakistan.

Karajeh, M., W. Abu. Gharbieh and S. Masoud. 2005. First report of root knot nematode Meloidogyne arenaria race 2 from several vegetable crops in Jordan. Pl. Dis. 89: 206.

Karseen, G. 2000. The plant-parasitic nematode genus Meloidogyne goeldi, 1892 (Tylenchida) in
Europe. Brill Academic Publishers, Leiden, The Netherlands: 319-392.

Kepenekci, I. and E. Evlice. 2004. Record of Root-knot nematodes in Turkey. Pak. J. Nemat. 22: 207211.

Khan, H. and R. Ahmad, 2000. Geographical distribution and frequency of occurrence of root-knot nematodes in Punjab-Pakistan. Int. J. Agric.Biol., 2: 354-355

Khan, H. U., W. Ahmed, R. Ahmed and M. A. Iqbal. 2006. Studies on the distribution and control of Meloidogyne root-knot nematodes in Faisalabad and Lahore divosions. Pak. J. of Nematol. 24: 57-64.

Khan, H.U., W. Ahmad and M.A. Khan. 2000. Evaluation of resistance in fifteen tomato cultivars against root-knot nematodes Meloidogyne incognita. Pak. J. Phytopathol. 12: 50-52.

Luc, M., R.A. Sikora and J. Bridge. 2005. Plant parasitic nematodes in tropic and subtropical agriculture. 2nd Edn. CAB International, Wallingford, Oxford, UK. 871-872.

Luzzi, B.M., H.R. Boerma and R.S. Hussey. 1987. Resistance to three species of root knot nematode in soybean. Crop Sci. 27:258-262.

Maqbool, M.A. 1986. Classification and distribution of plant parasitic nematodes in Pakistan. Pak. J. Nematol. 5: 15-17

Mehrotra, R.S. 1983. Plant Pathology, Tata McGraw Hill Pub. Co. Ltd., New Dehli. 730-731.

Ogbuji, R.O. 2004. Soil depth distribution of root knot nematode (Meloidogyne incognita) from two farmlands in a humid tropical environment. Geo Journal. 5: 79-80.

Powell, N.T. 1971. Interaction between nematodes and fungi in disease complex. Annu. Rev. Phytopath. 9:253-274.

Quesenberry, K.H., D.D. Baltensperger., R.A. Dunn., C.J. Wilcox and S.R. Hardy. 1989. Selection for tolerance to root knot nematodes in red clover. Crop. Sci. 29:62-65.

Radewald, K.C., J. Darsow., M.E. Stangelini and J.O. Becker. 2003. Quantitative Comparison of methods for recovery of root-knot nematode eggs from plant roots. Phytopathol. 93: 29.

Ravichandra, N.G. and K. Krishnappa. 2004. Prevalence and distribution of phytoparasitic nematodes associated with major vegetable crops in Mandya District, Karnataka. Ind. J. Nemat. 34: 113-116.

Rehman, A., B. Rubab and M.H. Ullah. 2006. Evaluation of different chemicals, against root-knot nematode (Meloidogyne incognita) on sunflower. J. Agric. Soc. Sci. 2: 185-186. 
Roberts, P.A. 1987. The influence of planting date of carrot on Meloidogyne incognita reproduction and injury to roots. Nemtologica. 33: 335-342.

Sahi, M.H. 2008. Reaction of Okra cultivars to root knot nematode, Meloidogyne incognita infection. M.Sc. Thesis. Dept. Pl. Pathol. Univ. Agri.,Faisalabad, Pakistan.

Sajjad, M. 2004. Screening of tomato varieties against root-knot nematodes (Meloidogyne incognita). M.Sc. Thesis. Dept. Pl. Pathol. Univ. of Agri., Faisalabad, Pakistan.

Shahzad, S. A., R. Ahmad and M. Inam-ul-Haq. 1999. Screening of tomato cultivars against root knot nematode (Meloidogyne incognita). Pak. J. Phytopath. 11: 74-76.

Sikora, R.A. and E. Fernandez. 1990. Nematode parasites of vegetables. In Plant parasitic nematodes in subtropical and tropical agriculture (eds. M. R. Luc, A. Sikora and J. Bridge). CAB Bioscience, Egham, UK. 319-392.

Sikora, R.A. and E. Fernandez. 2005. Nematode parasites of vegetables. p. 319-392. In M. Luc., R.A. Sikora and J. Bridge (eds.). Plant-Parasitic nematodes in subtropical and tropical agriculture (2nd Ed.). CABI Pub. Wallingford, UK.

Southey, J.F. 1986. Laboratory methods for work in plant and soil nematodes. Ministry of Agriculture, Fisheries and Food, London. 202202.
Starr, J.L., C.M. Heald, A.F. Robinson, R.G. Smith, J.P. Krausz. incognita and Rotylenchulus reniformis and associated soil textures from some cotton production areas of Texas. J. Nematol. 25: 895899.

Steel, R.G., J.H. Torrie and D.A. Deekey. 1997. Principles and Procedures of Statistics. A biometrical approach 3rd edition. Mc Graw Hill book Co., New York.

Taylor, A.L and J.N. Sasser. 1978. Biology, Identification and control of root knot nematodes (Meloidogyne spp.). Coop. Pub. Deptt. Plant Pathology. North Carolina State University and United States Agency for International Development, Graphics, Raleigh. 111-116.

Ubaid, M. 2009. Host suitability of summer vegetable genotypes to Meloidogyne incognita. M.Sc. Thesis. Dept. Pl. Pathol. Univ. Agri., Faisalabad, Pakistan.

Younis, M., M.A. Khan, S.T. Sahi, and R. Ahmad. 2009. Genotypic Variations among different potato lines/varieties for tolerance against late blight disease. Pak. J. Phytopathol. 21: 13-17.

Zia, A., S.A. Anwar and N. Javed. 2008. Host status of sugar beets genotype to Meloidogyne incognita. Ind. J. Nematol. 18: 71-74.

Publisher's note: EScience Press remains neutral with regard to jurisdictional claims in published maps and institutional affiliations.

Open Access This article is licensed under a Creative Commons Attribution 4.0 International License. To view a copy of this license, visit http://creativecommons.org/licenses/by/4.0/.

(C) The Author(s) 2012 